\title{
A Study on the Levels of Heavy Metals in Poultry Eggs in Chittoor District of Andhra Pradesh, India
}

\author{
A. Jagadeesh Babu ${ }^{1}$, C.S. Swetha ${ }^{1}$, R.A. Supriya ${ }^{1}$, G. Suganya ${ }^{1 *}$, K. Sasikala ${ }^{2}$, \\ R. Surendra ${ }^{2}$ and K. Yeshwanth Srinivas ${ }^{2}$
}

${ }^{1}$ Department of Veterinary Public Health and Epidemiology, Sri Venkateswara Veterinary University, College of Veterinary Science, Tirupati, Andhara Pradesh, India

${ }^{2}$ B.V.Sc, Sri Venkateswara Veterinary University, College of Veterinary Science, Tirupati, Andhra Pradesh, India

*Corresponding author

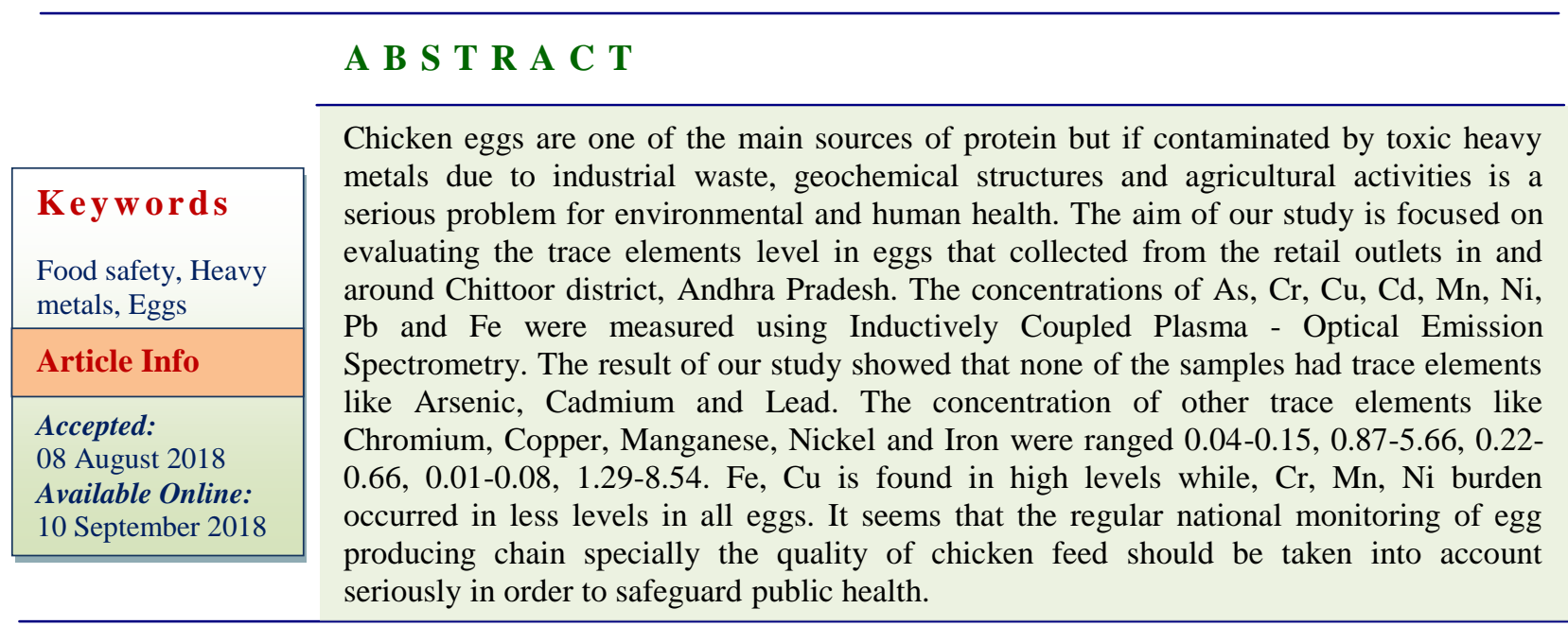

\section{Introduction}

The poultry industry is one of the largest sectors of agriculture throughout the world and the intensive poultry farming being increased the supply of economical, palatable and healthy food protein for growing urban populations. Despite substantial interest in the trace element content of eggs by poultry breeders, nutritionists and environmental scientists, available data about trace elements levels in eggs are scarce. Chicken eggs are one of the main sources of protein but if contaminated by toxic heavy metals due to industrial waste, geochemical structures and agricultural activities is a serious problem for environmental and human health Singh et al., (2007).

Apart from these, chickens are also exposed to heavy metals by feed intake. Poultry could take up heavy metal from different sources, especially via nutrition. Therefore, metal residues may concentrate in their meat, and 
eggs Nisianakis et al., (2009), Chowdhury et al., (2011); Abdulkhaliq et al., (2012) and consequently, the metals are passed to humans through chicken eggs. Since hen's eggs are considered as one of nature's highly-nutritious and economical food items in human daily diet, especially that of the children, it is of high account for human health, Surai and Sparks (2001); ALAshmawy (2013). Metallic elements are found in all living organisms where they play a variety of roles, as structural, components of control mechanisms (e.g. in nerves and muscles) and enzyme activator. Some metals are essential as copper $(\mathrm{Cu})$, zinc $(\mathrm{Zn})$, calcium $(\mathrm{Ca})$, iron $(\mathrm{Fe})$ and magnesium $(\mathrm{Mg})$ those play a definitive role in the intrinsic mechanisms regulating vital biological processes. Whereas others are nonessential metals and even toxic in trace amounts, especially lead $(\mathrm{Pb})$, cadmium $(\mathrm{Cd})$, mercury ( $\mathrm{Hg}$ ) and arsenic (As), Dundar and Deryaoglu (2005).

Heavy metal contamination is a serious threat because of their toxicity, bio-magnification and bioaccumulation in food chain. The deficiency of elements leads to impairment of vital biological process but when they are present in excess, they become toxic. Copper is an essential trace element, normal constituent of animal tissues and fluids, crucial in haemoglobin synthesis and other enzymes functions. Toxic level of $\mathrm{Cu}$ may lead to Wilson's disease (excessive accumulation of $\mathrm{Cu}$ in liver, brain, kidney and cornea) and Menkes's disease, Tapero et al., (2003). Zinc plays an important role in the maintaining of structure and function of large number of macromolecules and for over 300 enzymatic reactions, Prasad (1995) and also plays a role in immune function, protein synthesis, wound healing, DNA synthesis and cell division; consequently it supports normal growth and development during pregnancy, childhood and adolescence. Lead ingested by chicken through contaminated feed is deposited in bones and soft tissue. Development of abnormalities, deficits in intelligence quotient and neurotoxicity effects in infants, incidence constipation, colic, and anaemia are the main consequences of chronic exposure to $\mathrm{Pb}$, Hariri et al., (2015).

Cadmium is a toxic to virtually every system in the animal body. It is almost absent in the human body at birth but accumulates with age. However food is the primary source of cadmium exposure and its adverse health effects occur in the form of kidney damage but possibly also bone effects and fracture, Trampel et al., (2003). It is also listed as a human carcinogen in Group 1 by the IARC. Decreased rate of glomerular filtration, significant proteinuria, and increased frequency of kidney stone formation are the chronic effects of oral exposure to this metal. Chromium is an essential element for human beings, especially since it acts on the organism, maintaining normal glucose tolerance. Chromium (III), found in most food and nutrient supplements, is an essential nutrient with very low toxicity, whereas $\mathrm{Cr}$ (VI) compound have been shown to be potent occupational carcinogens. Stainless steel vessels seem to be the main source of this element's contamination.

Iron is an essential trace element whose biological importance arises from its involvement in vital metabolic function by being cytochromes, Iron deficiency is the most prevalent single nutritional deficiency in the world and is the main cause of anaemia in infants, children, adolescents and woman of child bearing age. Manganese is usually occurring with iron and it one of the most abundant metal in the earth's crust. Manganese perform significant part in different metabolic process in human, animals, microorganism and plants the deficiency of manganese is very rare that is its presence everywhere and is found in many food. 
The human health risk assessment requires identification, collection, and integration of information on hazardous chemicals, their exposure to humans, and also the relationship between exposure, dose, and adverse health effects Sobhanardakani (2017). Eggs are generally consumed by members of different income classes; thus this product's contamination can cause problems to consumers.

Hence immediate action required by the health regulatory authorities and the researchers in order to control the hazard due to heavy metals hazard which is being highly sensitive in posing risk to public health. There is a serious need of local database or risk assessment studies in local animals and foodstuffs to evaluate the potential risk or threat to humans from heavy metals because the Asian countries have different environmental and topographical conditions under which a large number livestock and poultry are growing.

Therefore the present study was designed to evaluate the levels of selected heavy metals (As, $\mathrm{Cr}, \mathrm{Cu}, \mathrm{Cd}, \mathrm{Mn}, \mathrm{Ni}, \mathrm{Pb}$ and $\mathrm{Fe}$ ) in egg to safeguard the public health in Chittoor district, Andhra Pradesh. This study will be useful in determining the potential risks from the toxic effects of heavy metals and to make recommendations for future implementations by the local health regulatory authorities.

\section{Materials and Methods}

The present study was carried out at the Department of Veterinary Public Health and Epidemiology, College of Veterinary Science, Tirupati, Sri Venkateswara Veterinary University to estimate the level of heavy metal residues viz $\mathrm{As}, \mathrm{Cr}, \mathrm{Cu}, \mathrm{Cd}, \mathrm{Mn}, \mathrm{Ni}, \mathrm{Pb}$, Feusing Inductively Coupled Plasma Optical Emission Spectrometry method (ICP-OES). Hen's egg samples (commercially produced, home produced and organic eggs) were collected from different shops, homes and supermarkets in and around chittoor district of Andhra Pradesh. The egg samples $(n=26)$ collected aseptically and carried to the laboratory in sterile polythene bags. The samples were maintained at $4^{\circ} \mathrm{C}$ until processing.

\section{Sample preparation}

The procedure mentioned by Belton P.S. (2006) was adopted in this experiment for the preparation of the sample to determine heavy metals like Arsenic, Chromium, Copper, Cadmium, Manganese, Nickel, lead and Iron. The collected egg samples were cleaned and washed with demineralized water. Each egg were cut in the air cell end using pointed forceps and dissecting scissors was sterilized and rinsed with distilled water for each egg.

The content of each sample were placed in a chemically clean glass jar and weighed then blended. Samples were dried at $75^{\circ} \mathrm{C}$ until constant weight was obtained. The dried egg samples were subjected to digestion for further analysis by using wet digestion procedure. As per this method two grams of the sample was placed in a digestion tube and pre-digested in $10 \mathrm{ml}$ concentrated $\mathrm{HNO}_{3}$ at $135^{\circ} \mathrm{C}$ until the liquor was clear.

Thereafter, $10 \mathrm{ml}$ of $\mathrm{HNO}_{3}, 1 \mathrm{ml}$ of $\mathrm{HClO}_{4}$ and $2 \mathrm{ml}$ of $\mathrm{H}_{2} \mathrm{O}_{2}$ was added and temperature was maintained at $135^{\circ} \mathrm{C}$ for 1 hour until the liquor becomes colourless. The product of the digestion was allowed to evaporate slowly to near dryness. The dried product after digestion cooled and dissolved in $1 \mathrm{M} \mathrm{HNO}$. The digest was subsequently filtered through Whatman filter paper No. 1 and diluted to $25 \mathrm{ml}$ with $1 \mathrm{M} \mathrm{HNO}_{3}$. The digested liver samples were presented for Inductively Coupled Plasma Optical emission Spectrometry method (ICPOES). 


\section{Determination of heavy metals}

Standard curve for the analysis of heavy metals like $\mathrm{As}, \mathrm{Cr}, \mathrm{Cu}, \mathrm{Cd}, \mathrm{Mn}, \mathrm{Ni}, \mathrm{Pb}$ and $\mathrm{Fe}$ was prepared from stock solutions (standard concentrations of $1000 \mathrm{mg} / \mathrm{ml}$ ) of analytes. To cover the optimum emission working range (0.01 to $5.00 \mathrm{mg} / \mathrm{ml}$ ) further serial dilutions were prepared. Usually freshly stored standard curves in the system software, where available and the same were used. Blank solutions were also being prepared accordingly.

For the determination of $\mathrm{As}, \mathrm{Cr}, \mathrm{Cu}, \mathrm{Cd}, \mathrm{Mn}$, $\mathrm{Ni}, \mathrm{Pb}$ and $\mathrm{Fe}$ from the egg samples the standard methods adopted by Boss and Fredeen (1997). As per the procedure of these scientists Inductively Coupled Plasma Optical Emission Spectrometry (ICP-OES Model) was used for the determination of As, $\mathrm{Cr}, \mathrm{Cu}, \mathrm{Cd}, \mathrm{Mn}, \mathrm{Ni}, \mathrm{Pb}$ and $\mathrm{Fe}$ from the egg samples. During this experiment the samples were analyzed under the instrumental operating conditions like RF power $1.0 \mathrm{~kW}$, outer argon flow $12.0 \mathrm{~L} / \mathrm{min}$, intermediate and inner argon flow $1.0 \mathrm{~L} / \mathrm{min}$ and the nebulizer uptake rate $(\mathrm{ml} / \mathrm{min})$ was 1.0. Samples were run in replicate and integrated computer results of the determination will be recorded.

\section{Results and Discussion}

The result of our study showed that the concentration of other trace elements like chromium, Copper, Manganese, Nickel and Iron were ranged 0.04-0.15, 0.87-5.66, 0.22$0.66,0.01-0.08$ and $1.29-8.54$ respectively (Table 1) (Fig. 1 and 2). Fe, $\mathrm{Cu}$ is found in high levels while, $\mathrm{Cr}$, Mn, Ni burden occurred in less levels in all birds eggs. The average of the concentration of the heavy metals in egg samples $\mathrm{Cr}, \mathrm{Mn}, \mathrm{Ni}, \mathrm{Fe}$ and $\mathrm{Cu}$ were 0.06 , $0.40,0.50,4.63$ and 1.98 respectively. The result of our study showed that none of the samples had trace elements like arsenic, chromium, cadmium and lead. The mean and standard deviation of the concentration of heavy metals are listed in (Table 2).

A study was conducted by Zafar Khanet al., (2016) in Peshawar found the liver contains significantly higher concentration of lead $(\mathrm{Pb})$, Cadmium (Cd), Chromium $(\mathrm{Cr})$, Iron $(\mathrm{Fe})$, Manganese (Mn) and Zinc ( $\mathrm{Zn})$ as compared to thigh and breast muscle and the mean concentrations of toxic heavy metals; $\mathrm{Pb}, \mathrm{Cd}$ and $\mathrm{Cr}$ in albumen samples were 0.13, 0.06 and 0.09 (ppm) respectively. Concentrations of $\mathrm{Pb}, \mathrm{Cd}$ and $\mathrm{Cr}$ in egg albumen of Dir Lower were $0.13,0.05$ and 0.05 and in Malakand were $0.12,0.05$ and $0.07 \mathrm{ppm}$, respectively.

The mean concentrations of essential elements $\mathrm{Fe}, \mathrm{Mn}$ and $\mathrm{Zn}$ in egg yolk of Peshawar were 1.27, 0.31 and 2.05 while that of Dir Lower were $1.05,0.19$ and $1.97 \pm 0.04 \mathrm{ppm}$, respectively. The mean levels of $\mathrm{Fe}, \mathrm{Mn}$ and $\mathrm{Zn}$ in egg yolk from Malakand were 1.13, 0.20 and 2.00 $\pm 0.06 \mathrm{ppm}$, respectively.

Another study by Demirulus (2013) revealed the average concentrations of heavy metals were found as follows: $\mathrm{Zn}$ : $35.6 \mathrm{ppm}$ and 42.2 $\mathrm{ppm}$ in yolk, $4.3 \mathrm{ppm}$ and $7.4 \mathrm{ppm}$ in albumen; $\mathrm{Cu}$ : $2.7 \mathrm{ppm}$ and $10.5 \mathrm{ppm}$ in yolk, $7.0 \mathrm{ppm}$ and $1.5 \mathrm{ppm}$ in albumen; $\mathrm{Cd}: 0.34$ ppm and $1.24 \mathrm{ppm}$ in yolk, $0.31 \mathrm{ppm}$ and 1.25 ppm in albumen; Mn: $1.9 \mathrm{ppm}$ and $6.8 \mathrm{ppm}$ in yolk, $2.0 \mathrm{ppm}$ and $4.5 \mathrm{ppm}$ in albumen; Ni: $1.7 \mathrm{ppm}$ and $3.1 \mathrm{ppm}$ in yolk, $2.8 \mathrm{ppm}$ and 3.7 ppm in albumen respectively and several studies conducted by different authors like Farhani et al., (2015) found the mean concentrations of heavy metals in egg-white as follows: 0.119 for $\mathrm{Al}, 0.785$ for As, 0.750 for $\mathrm{Pb}, \quad 0.249$ for $\mathrm{Cd}, 0.270$ for $\mathrm{Hg}$ and $0.186 \mathrm{mg} / \mathrm{kg}$ for $\mathrm{Sb}$ and similarly Abbasi et al., (2015)showed the mean concentrations of cadmium, lead, arsenic, nickel, copper, iron and zinc in collected chicken eggs were 0.01 , $0.074,0.03,0.014,1.46,34.37$ and 12.55 $\mathrm{mg} / \mathrm{kg}$, respectively. 
Table.1 Showing the concentration of heavy metals in egg samples (ppm) by Inductively Coupled Plasma - Optical Emission Spectrometry

\begin{tabular}{|c|c|c|c|c|c|}
\hline $\begin{array}{c}\text { SAMPLE } \\
\text { NO }\end{array}$ & CHROMIUM & MANGANESE & NICKEL & IRON & COPPER \\
\hline $\mathbf{1}$ & 0 & 0.263 & 0.025 & 1.554 & 1.12 \\
\hline $\mathbf{2}$ & 0.061 & 0.277 & 0.047 & 3.225 & 0.087 \\
\hline $\mathbf{3}$ & 0.054 & 0.347 & 0.018 & 3.189 & 2.35 \\
\hline $\mathbf{4}$ & 0.041 & 0.441 & 0.022 & 5.341 & 1.28 \\
\hline $\mathbf{5}$ & 0.055 & 0.412 & 0.024 & 4.526 & 0.98 \\
\hline $\mathbf{6}$ & 0.084 & 0.357 & 0.057 & 8.225 & 1.27 \\
\hline $\mathbf{7}$ & 0.037 & 0.227 & 0.044 & 8.541 & 5.66 \\
\hline $\mathbf{8}$ & 0.082 & 0.257 & 0.053 & 5.367 & 4.57 \\
\hline $\mathbf{9}$ & 0.055 & 0.524 & 0.087 & 2.158 & 0.87 \\
\hline $\mathbf{1 0}$ & 0.05 & 0.664 & 0.043 & 2.571 & 1.58 \\
\hline $\mathbf{1 1}$ & 0.067 & 0.247 & 0.037 & 5.324 & 2.34 \\
\hline $\mathbf{1 2}$ & 0.052 & 0.319 & 0.049 & 4.589 & 1.08 \\
\hline $\mathbf{1 3}$ & 0.0957 & 0.665 & 0.057 & 3.664 & 2.22 \\
\hline $\mathbf{1 4}$ & 0.102 & 0.348 & 0.055 & 8.547 & 1.97 \\
\hline $\mathbf{1 5}$ & 0 & 0.525 & 0.029 & 5.664 & 1.55 \\
\hline $\mathbf{1 6}$ & 0 & 0.354 & 0.068 & 7.658 & 1.49 \\
\hline $\mathbf{1 7}$ & 0.124 & 0.429 & 0.071 & 5.367 & 3.24 \\
\hline $\mathbf{1 8}$ & 0.075 & 0.712 & 0.049 & 3.35 & 1.59 \\
\hline $\mathbf{1 9}$ & 0.088 & 0.274 & 0.051 & 5.124 & 1.27 \\
\hline $\mathbf{2 0}$ & 0.114 & 0.366 & 0.043 & 6.66 & 1.8 \\
\hline $\mathbf{2 1}$ & 0.081 & 0.297 & 0.071 & 4.246 & 1.6 \\
\hline $\mathbf{2 2}$ & 0.057 & 0.269 & 0.059 & 3.278 & 0.98 \\
\hline $\mathbf{2 3}$ & 0.08 & 0.557 & 0.047 & 1.295 & 1.41 \\
\hline $\mathbf{2 4}$ & 0.089 & 0.442 & 0.076 & 2.506 & 2.07 \\
\hline $\mathbf{2 5}$ & 0.153 & 0.382 & 0.081 & 2.387 & 4.55 \\
\hline $\mathbf{2 6}$ & 0.097 & 0.476 & 0.057 & 6.214 & 2.61 \\
\hline & & & & & \\
\hline
\end{tabular}

Table. 2 Showing the average, mean, standard deviation of heavy metals in egg samples

\begin{tabular}{|c|c|c|c|c|}
\hline S.NO & $\begin{array}{c}\text { HEAVY } \\
\text { METALS IN } \\
\text { EGGS }\end{array}$ & AVERAGE & MEAN & $\begin{array}{c}\text { STANDARD } \\
\text { DEVIATION }\end{array}$ \\
\hline $\mathbf{1}$ & CHROMIUM & 0.068 & $0.071 \pm 0.007$ & 0.036 \\
\hline $\mathbf{2}$ & MANGANESE & 0.401 & $0.401 \pm 0.026$ & 0.137 \\
\hline $\mathbf{3}$ & NICKEL & 0.050 & $0.050 \pm 0.003$ & 0.018 \\
\hline $\mathbf{4}$ & IRON & 4.630 & $4.637 \pm 0.414$ & 2.115 \\
\hline $\mathbf{5}$ & COPPER & 1.982 & $1.982 \pm 0.248$ & 1.269 \\
\hline
\end{tabular}


Fig.1 Showing the average concentration of manganese in eggs (ppm) by inductively coupled plasma - optical emission spectrometry

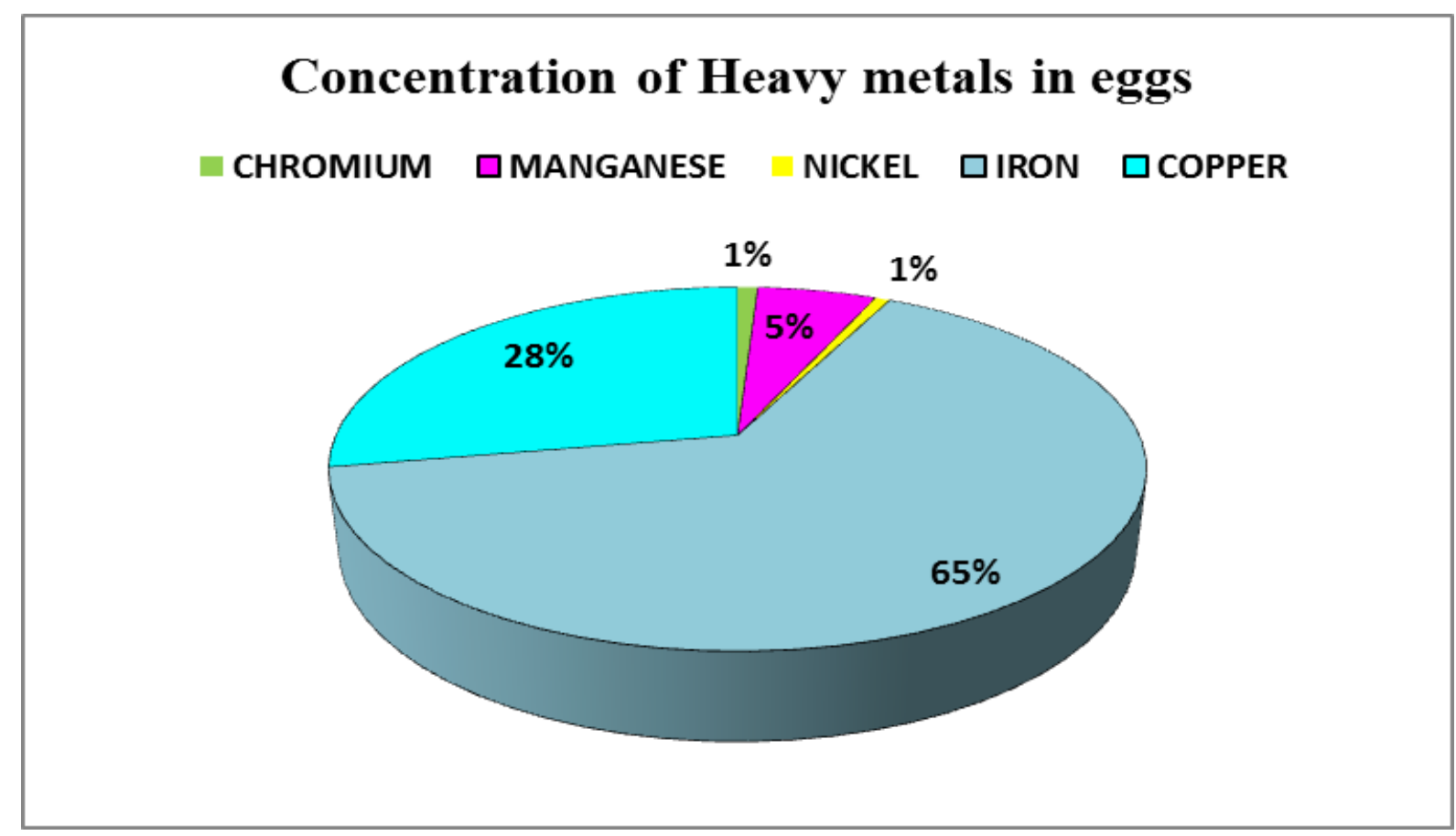

Fig.2 Showing the average concentration of manganese in eggs (ppm) by inductively coupled plasma - optical emission spectrometry

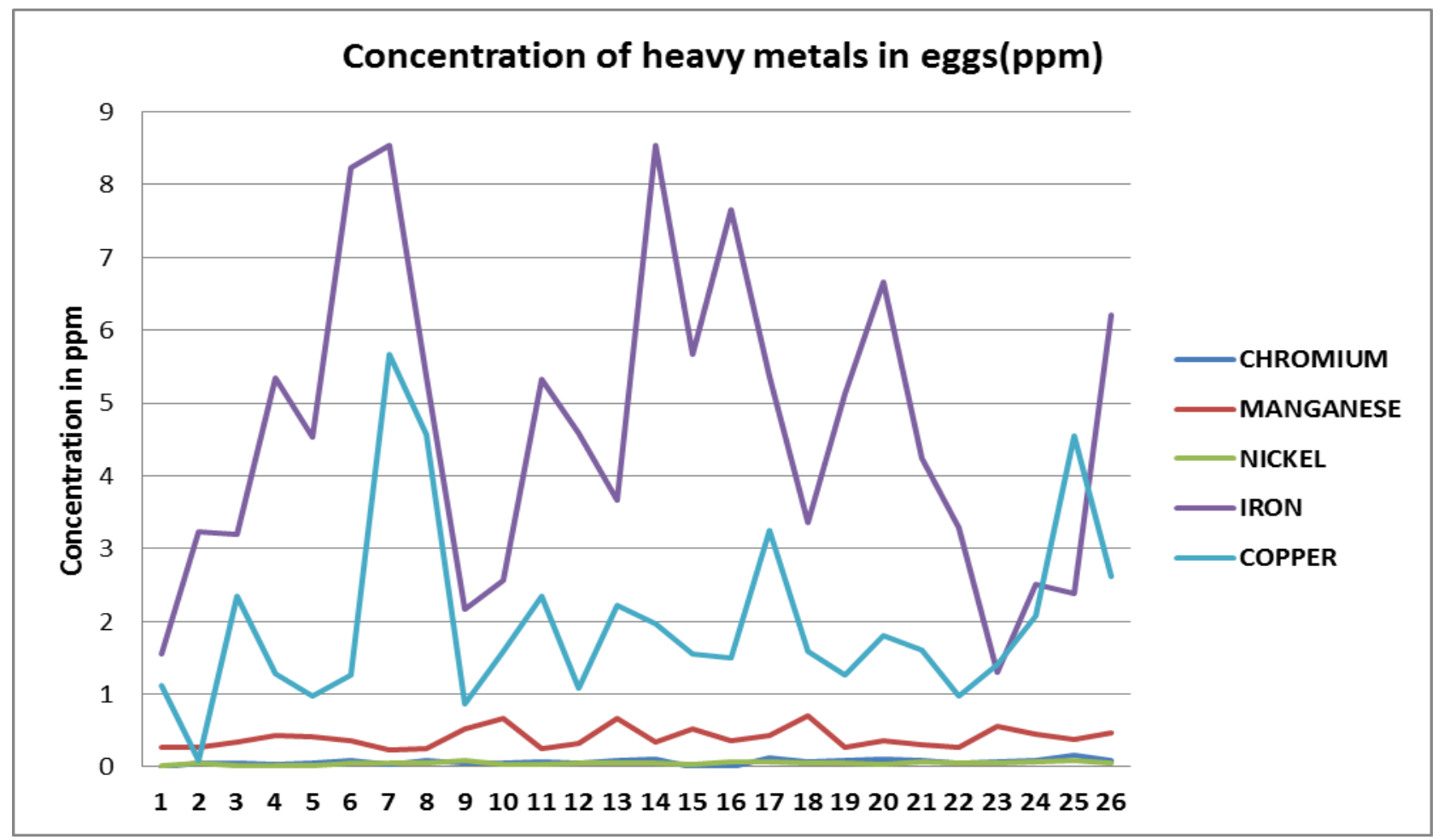


Sobhanardakani (2017) reported the mean concentrations $(\mathrm{mg} / \mathrm{kg})$ of $\mathrm{Pb}, \mathrm{Cd}, \mathrm{Cr}$, and $\mathrm{Cu}$ in the samples has been $0.29 \pm 0.16,0.18 \pm 0.04$, $0.31 \pm 0.03$, and $2.81 \pm 1.56$, respectively. Also, the mean contents of $\mathrm{Cd}$ and $\mathrm{Cr}$ have surpassed the maximum permissible levels (MPL), established by WHO/FAO.

The Study conducted on the important heavy metal (i.e.) lead by Trampel et al., (2003) found the contamination of the lead in yolks varied from less than 20 to $400 \mathrm{ppb}$, and shells were found to contain up to $450 \mathrm{ppb}$ lead though Albumen contained no detectable amount and also they have correlated lead content of the egg yolks with blood lead levels but the deposition of lead in the shells did not correlate well with blood lead levels and they revealed that mean tissue lead accumulation was highest in kidneys $(1,360$ $\mathrm{ppb})$, with livers ranking second $(500 \mathrm{ppb})$ and ovarian tissue third (320 ppb). Muscle contained the lowest level of lead $(280 \mathrm{ppb})$ and his study about lead contamination of egg yolks and edible chicken tissues represents a potential public health hazard. Likewise Dey and Dwivedi (2010) detected the limits for $\mathrm{Cd}$ and $\mathrm{Pb}$ was $0.001 \mathrm{pg} / \mathrm{g}$ and $0.02 \mathrm{pg} / \mathrm{g}$, respectively and the $\mathrm{Pb}$ concentration in egg samples ranged between 0.142 and $0.936 \mathrm{pg} / \mathrm{g}$ (mean k standard deviation: $0.489 \mathrm{k} 0.081$ $\mathrm{pg} / \mathrm{g}$ ), and $\mathrm{Cd}$ concentrations ranged between 0.030 and $0.180 \mathrm{pg} / \mathrm{g}(0.072 \mathrm{f} 0.004 \mathrm{pg} / \mathrm{g})$. In his study, the majority of samples had $\mathrm{Pb}$ and $\mathrm{Cd}$ concentrations that exceeded $0.020 \mathrm{pg} / \mathrm{g}$ and $0.005 \mathrm{pg} / \mathrm{g}$, respectively.

Spliethoffa et al., (2014) detected lead was between 10 and $167 \mu \mathrm{g} / \mathrm{kg}$ and were significantly associated $(\mathrm{p}<0.005)$ with lead concentrations in soil. The association between soil and egg lead has been evaluated in his study leads to denote the transfer efficiency from soil-to-egg and suggesting that there may be important geographic differences in this transfer. They have developed models that suggested that lead concentrations in $>50 \%$ of eggs from a henhouse would exceed store-bought egg concentrations $\quad(<7-13 \mu \mathrm{g} / \mathrm{kg} ; \quad 3 \%$ above detection limit) at soil lead concentrations $>120 \mathrm{mg} / \mathrm{kg}$, and that the concentration in one of six eggs from a henhouse would exceed a $100 \mu \mathrm{g} / \mathrm{kg}$ guidance value at soil lead concentrations $>410 \mathrm{mg} / \mathrm{kg}$. His models also suggested that the availability of dietary calcium supplements was another influential factor that reduced egg lead concentrations. Estimates of health risk from consuming eggs with the lead concentrations were measured generally were not significant.

In conclusion, with regards to presence of heavy metals in eggs, the necessity of vigorous regular national monitoring of eggs contamination as well as quality of safe animal feed as a main source of contamination should be emphasized. Feeds supplement added to hen's diet should be measured and calculated its residues in eggs to avoid undesirable increase in their amounts. Since knowledge of eggs' metal levels is becoming increasingly important and egg consumption is a bio indicator in addition to monitor environmental pollution.

\section{Acknowledgement}

The authors are thankful to College of Veterinary Science, Tirupati, Sri Venkateswara Veterinary University for providing permission to conduct the research work.

\section{References}

Abbasi K.S, Khaniki, G. J., Shariatifar, N., S. Nazmara and Akbarzadeh, A, 2015. Contamination of chicken eggs supplied in Tehran by heavy metals and calculation of their daily intake. Journal of health in the field, 2(4). 
Abdulkhaliq, A., Swaileh, K.M., Hussein, R.M. and Matani, M. (2012). Levels of metals $(\mathrm{Cd}, \mathrm{Pb}, \mathrm{Cu}$ and $\mathrm{Fe})$ in cow's milk, dairy products and hen's eggs from the West Bank, Palestine. Int. Food Res. J., 19(3): 1089-1094.

AL-Ashmawy, M.A.M. (2013). Trace elements residues in the table eggs rolling in the Mansoura City markets Egypt. Int. Food Res. J., 20(4): 17831787.

Belton, P.S. (2006). Trace Element Analysis of Food and Diet RSC FOOD ANALYSIS MONOGRAPHS Royal society of chemistry, Thomos Graham House Science Park, Milton road Cambridge, CB4 0WF, UK.

Boss, C.B and Freeden, K.J (1997). Concepts, Instrumentation and Techniques in Inductively Coupled Plasma Optic Emission Spectrometry, 2nd edition, Perkin Elmer Corporation, USA.

Chowdhury, M.Z.A., Siddique, A.A., Hossain, S.M.A., Kazi, A.I., Ahsan, A.A., Ahmed, S. and Zaman, M.M. (2011). Determination of essential and toxic metals in meats, meat products and eggs by spectrophotometric method.J. Bangladesh Chem. Soc., 24(2): 165-172.

Demirulus, H., (2013). The Heavy Metal Content in Chicken Eggs Consumed in Van Lake Territory. Ekoloji, 22 (86): 19-25.

Dey, S and Dwivedi, S. K., (2010).Toxic Metals in Hens' Eggs in India: A Preliminary Report. Archives of Environmental Health: An International Journal, 55(5):365-366.

Dundar, M. S. and Deryaoglu, N. (2005). Heavy metal determinations in outdoor atmospheric dust depositions. Fresenius Environ. Bull., 14:185-188.

Farahani, S., Eshghi, N., Abbasi, A., Karimi, F., ShiriMalekabad, E. and Rezaei, M. (2015). Determination of heavy metals in albumen of hen eggs from the Markazi Province (Iran) using ICP-OES technique. Toxin. Rev., 34(2): 96-100.

Hariri, E., Abboud, M.I., Demirdjian, S., Korfali, S., Mroueh, M. and Taleb, R.I. (2015). Carcinogenic and neurotoxic risks of acrylamide and heavy metals from potato and corn chips consumed by the Lebanese population. J. Food Compos. Anal., 42: 91-97.

Lurie, D.G., Holden, T.M., Schuberf, A., Wolf, W.R. and Miller-Ihli, N.J. (1990). The copper content of foods based on a critical evaluation of published analytical data. J. Food Compos. Anal., 2(4): 298-316.

Nisianakis, P., Giannenas, I., Gavriil, A., Kontopidis, G. and Kyriazakis, I. (2009). Variation in trace element contents among chicken, turkey, duck, goose, and pigeon eggs analyzed by inductively coupled plasma mass spectrometry (ICP-MS). Biol. Trace Elem. Res., 128(1): 62-71.

Pappas, A.C., Karadas, F., Surai, P.F.N.A.R., Wood, N.A.R., Cassey, P., Bortolotti, G.R. and Speake, B.K. (2006). Interspecies variation in yolk selenium concentrations among eggs of freeliving birds: The effect of phylogeny. J. Trace Elem. Med. Biol., 20: 155-160.

Prasad, A. S., 1995. Zinc: an overview. Nutrition, 11: 93-99.

Singh, R.K., Chavan, S.L. and Sapkale, P.H., (2007). Heavy metal concentrations in water, sediments and body tissues of red worm (Tubifex spp.) collected from natural habitats in Mumbai, India. Environ Monit Assess 129:471-81.

Sobhanardakani, S. 2017. Tuna fish and common kilka: Health risk assessment of metal pollution through consumption of canned fish in Iran. J. Consum Prot. Food Saf., 12(2): 157-163.

Spliethoffa, H.M., Mitchella, R. G., Ribaudoa, L. N., Taylorb, O., Shaylerc, 
H. A., Greened, V. and Oglesbyd, D., (2014). Lead in New York City Community Garden Chicken Eggs: Influential Factors and Health Implications. Environ Geochem Health, 36(4): 633-649.

Surai, P.F. and Sparks, N.H.C. (2001). Designer egg: from improvement of egg composition to functional food. Trends Food Sci. Technol., 12: 7-16.

Tapiero, H. and Tew, K.D., 2003. Trace elements in human physiology and pathology zinc and metallothioneins.
Biomedicine and pharmacotherapy, 57(9): 399-411.

Trampel, D.W., Imerman, P.M., Carson, T.L., Kinker, J.A. and Ensley, S.M., 2003. Lead contamination of chicken eggs and tissues from a small farm flock. J. Vet. Diagn. Invest. 15 (5): 418-422.

Zafar Khan, Asad Sultan, Rajwali Khan, Sarzamin Khan, Imranullah and Kamran Farid, 2016. Concentrations of Heavy Metals and Minerals in Poultry Eggs and Meat Produced in Khyber Pakhtunkhwa, Pakistan. Meat Sciences and Veterinary Public Health 1(1):4.

\section{How to cite this article:}

Jagadeesh Babu, A., C.S. Swetha, R.A. Supriya, G. Suganya, K. Sasikala, R. Surendra and Yeshwanth Srinivas, K. 2018. A Study on the Levels of Heavy Metals in Poultry Eggs in Chittoor District of Andhra Pradesh, India. Int.J.Curr.Microbiol.App.Sci. 7(09): 1113-1121. doi: https://doi.org/10.20546/ijcmas.2018.709.132 